\title{
STANDARDISASI CAT PEMANTUL PANAS UNTUK EFISIENSI ENERGI DAN PENGURANGAN EMISI GAS BUANG PADA BANGUNAN
}

\author{
Standardization of Solar Reflective Paint \\ for Energy Efficiency and Reduced Gas Emission at Buildings
}

\author{
Deni Cahyadi \\ Balai Besar Bahan dan Barang Teknik - Kementerian Perindustrian RI \\ Jl. Sangkuriang No.14, Bandung \\ Email : denb4t@gmail.com
}

\begin{abstract}
Abstrak
Cat pemantul panas merupakan produk yang dapat berfungsi sebagai media pendinginan secara pasif. Aplikasi cat jenis ini pada bagian atas atau atap bangunan, dapat memantulkan sebagian radiasi sinar matahari pada rentang panjang gelombang $300 \mathrm{~nm}$ s.d. $2500 \mathrm{~nm}$. Berkurangnya radiasi sinar matahari yang diserap oleh material gedung diperkirakan dapat mengurangi suhu ruangan di dalam gedung. Gedung-gedung yang di wilayah perkotaan di Indonesia hampir seluruhnya menggunakan alat pendingin ruangan. Penggunaan alat pendingin ruangan memerlukan energi listrik, instalasi, pemeliharaan berkala, perbaikan, dan emisi gas buang. Pemberian lapisan cat pemantul panas pada atap gedung, dapat membantu kerja alat pendingin ruangan, sehingga diharapkan penggunaan listrik lebih rendah, emisi gas buang yang dihasilkan akan turun, dan biaya dapat berkurang. Standar kualitas produk cat pemantul panas sangat diperlukan untuk mendorong pengembangan produk oleh produsen, melindungi konsumen dan meningkatkan daya saing. Kualitas produk cat pemantul panas dapat diketahui melalui pengujian fisika-kimia (yaitu: densitas, padatan total, waktu pengeringan, daya lekat, senyawa organik mudah menguap (VOC), dan kandungan logam berbahaya) dan unjuk kerja (yaitu: kestabilan penyimpanan, kondisi dalam kemasan, ketahanan terhadap bahan kimia, ketahanan terhadap cuaca, dan Solar Reflectance Index (SRI). Penyusunan standar spesifikasi untuk cat pemantul panas perlu mempertimbangkan faktor kondisi dan iklim yang berbeda pada setiap negara.
\end{abstract}

Kata kunci : cat, pemantul panas, pendinginan, standar, suhu

\begin{abstract}
Solar reflective paint is a product that can act as a passive cooling system. Application of reflective paint on the top or roof of the building, can reflect some of the sun's radiation with a wavelength range of $300 \mathrm{~nm}$ to $2500 \mathrm{~nm}$. The reduced solar radiation absorbed by the building material is expected to lower the room temperature inside the building. The use of air conditioners required electrical energy, installation, periodic maintenance, repairs, and exhaust emissions. The application of solar reflective paint on the roof of the building, can help the work of air conditioner, minimize electricity, decrease exhaust emissions, and reduce costs. Standard specification for heat reflecting paint products are needed to encourage product development by producers, protect consumers and improve competitiveness. Heat reflective paint quality can be determined through physical-chemical testing (i.e, density, total solids, drying time, adhesion, volatile organic compound (VOC), and hazardous metal content) and performance testing (i.e, storage stability, conditions in container, chemical resistance, weather resistance, and the Solar Reflectance Index (SRI)). The preparation of standard specifications for heat reflecting paint needs to take into account the different conditions and climate factors in each country.
\end{abstract}

Keywords : paint, solar-reflective, cooling, standard, temperature

\section{PENDAHULUAN}

Pengembangan dan penerapan teknologi hijau (green technology) merupakan salah satu upaya untuk memelihara sumber daya alam dan mengurangi dampak akibat pencemaran lingkungan yang dilakukan di berbagai negara, termasuk Indonesia. Kebijakan untuk mewujudkan kemandirian energi nasional seperti efisiensi energi, konservasi, dan penggunaan sumber energi baru dan terbarukan (EBT) terus didorong oleh pemerintah(BPPT, 2019), termasuk di sektor industri dengan adanya kebijakan Standar Industri Hijau (SIH) (Hutahaean, 2017).

Gedung atau bangunan tercatat sebagai penyumbang $40 \%$ bagian dari konsumsi energi di dunia dan memiliki kontribusi terhadap emisi gas buang secara global sekitar 30\% (Eicker, 2009). Penggunaan alat pendingin ruangan (AC, Air 
Conditioner) merupakan salah satu faktor utama yang menyebabkan besarnya konsumsi energi dari suatu gedung. Menurut Cristina Gamboa, salah satu ciri tempat tinggal yang lebih sehat menurut konsep green building adalah bangunan yang efisien dalam menggunakan energi (WGBC, 2018). Penggunaan energi secara efisien merupakan salah satu cara untuk mendukung kebijakan pemerintah di sektor energi.

Pengecatan untuk mengurangi panas akibat sinar matahari yang diterima oleh Gedung atau "cool coating concepts" telah banyak diteliti di berbagai negara. Menurut Pissello (2017), terdapat 260 publikasi dalam kurun waktu 10 tahun yang menunjukkan berbagai keuntungan yang dapat diperoleh dari cara pendinginan secara pasif menggunakan konsep pengecatan dingin untuk kondisi lingkungan di dalam ruangan dan di luar ruangan suatu bangunan. Penelitian lanjutan dilakukan antara lain untuk membuktikan hal berikut: (i) Efek pengecatan dingin terhadap pedestrian, (ii) peran pengecatan dingin untuk optimasi HVAC (Heating, Ventilation and Air Conditioning), dan (iii) kombinasi antara pengecatan dingin dengan teknik penyimpanan energi panas (Pisello, 2017).

Aplikasi cat pemantul panas (cool paint) sebagai media pendinginan pasif (passive cooling) pada bangunan di Kawasan Mediterania yang dilakukan oleh V. Costanzo (2013), menunjukkan bahwa bangunan yang diberi lapisan cat pemantul panas mampu menurunkan kebutuhan listrik untuk pendinginan ruangan sebesar $5 \%$ - $12 \%$ dibandingkan dengan bangunan tanpa lapisan cat (Costanzo et al., 2013). Pembangunan dengan konsep green building memberikan dampak sosial, ekonomi, dan lingkungan. Aplikasi cat pemantul panas pada bangunan, dapat menjadi teknik tambahan selain penggunaan pemanas air sel surya, panel surya, kincir angin, dan desain sirkulasi; yang dikembangkan pada konsep green building.

Pemanfaatan cat pemantul panas di Kawasan beriklim tropis yang dilakukan di tiga negara (Jamaika, Brazil, dan Ghana) oleh Kolokotroni, et.al (2018), menunjukkan bahwa penggunaan cat pemantul panas pada atap bangunan mampu menurunkan suhu rata-rata pada permukaan langit-langit ruangan sebesar $3,2^{\circ} \mathrm{C}-5,5^{\circ} \mathrm{C}$, dengan estimasi potensi penghematan daya listrik sebesar 190 $\mathrm{kWh} / \mathrm{m}^{2} /$ tahun. Bangunan yang diberi lapisan cat pemantul panas dapat menurunkan suhu ruangan berventilasi alami dan mampu mengurangi kebutuhan energi akibat penggunaan pendingin ruangan pada gedung berpendingin ruangan (Kolokotroni et al., 2018).
Pengecatan atap gedung diharapkan mampu mengurangi penggunaan pendingin ruangan. Indonesia selaku negara tropis dengan paparan sinar matahari sepanjang tahun memerlukan memerlukan teknik pendinginan ruangan atau bangunan yang hemat energi. Menurut penelitian yang dilakukan oleh Irma Handayani Lubis (2018), penyerapan panas (heat gains) dan beban pendinginan (cooling loads) pada rumah di kota Medan pada siang hari yang cerah dapat dikurangi dengan cara mengatur kemiringan atap, memperluas beranda, menambahkan insulasi pada struktur atap, dan penggunaan lapisan cat yang memiliki reflektansi tinggi (cat pemantul panas)(Lubis and Koerniawan, 2018).

Pemanfaatan cat pemantul panas pada bangunan memberikan keuntungan, antara lain: dapat mengurangi konsumsi energi untuk mendinginkan bangunan, dapat memberikan perlindungan terhadap material bangunan dari kerusakan akibat korosi, dan memiliki fungsi dekoratif. Industri cat di Indonesia beberapa diantaranya sudah mampu memproduksi produk cat pemantul panas, sehingga perlu didukung dengan adanya standar spesifikasi produk dan riset yang mampu meningkatkan kualitas produknya. Parameter mutu yang tepat sangat penting untuk dapat menghasilkan produk dengan kualitas yang baik dan sesuai dengan kondisi di Indonesia. Penelitian ini bertujuan untuk memberikan gambaran parameter persyaratan mutu produk yang diharapkan dapat menjadi salah satu bahan referensi untuk merumuskan Standar Nasional Indonesia (SNI) terkait produk cat pemantul panas.

\section{TINJAUAN PUSTAKA}

Cat pemantul panas (solar-reflective paint) adalah cat yang diformulasi secara khusus, sehingga mampu memantulkan sinar matahari lebih tinggi dari cat jenis lain (JIS K5675-2011, 2011), dikenal juga dengan istilah cool paint atau cool roof paints. Secara alamiah kemampuan memantulkan atau menyerap panas dipengaruhi oleh warna lapisan cat. Warna putih dan hitam dijadikan standar dalam pengukuran SRI (Solar Reflective Index). Nilai indeks untuk atap berwarna putih adalah seratus (solar reflectance $=0,80$; thermal emittance $=0,90)$ dan atap berwarna hitam adalah nol (solar reflectance $=$ $0,05$; thermal emittance $=0,90)$ (Akbari and Levinson, 2008). Nilai SRI merupakan indikator dari kemampuan lapisan cat dalam memantulkan panas, cat pemantul panas diharapkan memiliki indeks SRI yang lebih tinggi daripada cat lain dengan warna yang sama. 
Sinar matahari yang sampai ke permukaan bumi memiliki rentang panjang gelombang antara $300 \mathrm{~nm}$ s.d. $2500 \mathrm{~nm}$ (Total Solar Radiation, TSR), yang terdiri dari radiasi sinar ultraviolet $(<400 \mathrm{~nm})$, sinar tampak (400 $700 \mathrm{~nm}$ ), dan infra-merah (> $700 \mathrm{~nm})$. Radiasi sinar matahari yang diserap oleh permukaan bangunan akan menyebabkan peningkatan panas pada bangunan, semakin banyak radiasi yang dipantulkan, maka panas yang diterima oleh bangunan akan semakin rendah. Peningkatan kemampuan cat dalam memantulkan panas pada umumnya dilakukan dengan cara: (i) Memilih pigmen yang secara alamiah mampu memantulkan panas dengan baik, (ii) Menambahkan butiran kaca/keramik yang mampu memantulkan radiasi sinar matahari, dan (iii) Mengembangkan teknik/desain pengecatan(Pockett, 2016).

Formulasi cat pemantul panas (solar reflective coating) dengan pemilihan dan penambahan material yang memiliki sifat emisi cahaya yang tinggi seperti alumunium oksida $\left(\mathrm{Al}_{2} \mathrm{O}_{3}\right)$, titanium dioksida $\left(\mathrm{TiO}_{2}\right)$, aluminium trihidrat $\left(\mathrm{Al}(\mathrm{OH})_{3}\right)$, dan silicon dioksida $\left(\mathrm{SiO}_{2}\right)$. Contoh formula yang terdiri dari campuran resin ester-akrilat sebanyak $15-30 \%$; alkid dispersion = 8-15\%; TEA (Tri-Etanol Amin) = 1-2\%; thickener $=0.3-1 \%$; defoamer (poli-silpksan) 0,25-0,5\%; silikon dioksida $\left(\mathrm{SiO}_{2}\right)=5-10 \%$; pigmen alumunium $=5-20 \%$; titanium dioksida $=0-14 \%$; dan air $=35-65 \%$, mampu meningkatkan kemampuan memantulkan sinar matahari sebesar $20 \%$ dibandingkan dengan permukaan beton (konkret) yang tidak dilapisi(Sarazyn, 2014). Jenis cat berbasis air maupun berbasis pelarut organik dapat berfungsi sebagai cat pemantul panas akibat sinar matahari.

Kemampuan cat dalam memantulkan sinar matahari supaya tetap efektif, perlu dilengkapi dengan peningkatan karakteristik lain, seperti: kemampuan penetrasi ke dalam substart, tidak tembus air (water repellency), ketahanan gesek, dan ketahanan terhadap cuaca. Penelitian untuk meningkatkan sifat hidrofobik cat pemantul panas dilakukan oleh Surendra Maharjan, dkk., dengan memformulasikan anatase $\mathrm{TiO}_{2}$ ke dalam organosiloksan menggunakan metode sol-gel. Penurunan suhu yang terjadi di dalam substrat CMC (Cement Mortas Composite) mencapai $4,1^{\circ} \mathrm{C}$ (Maharjan et al., 2020). Substitusi material $\mathrm{TiO} 2$ dan $\mathrm{ZnO}$ dalam cat berwarna putih dengan pigmen ZnTiO3 (optical band gap $=3,75 \mathrm{eV}$ ) yang dilakukan oleh Jinpeng Lv, mampu menurunkan suhu sebesar $14,9^{\circ} \mathrm{C}$, lebih rendah $4,6^{\circ} \mathrm{C}$ dibandingkan dengan menggunakan material $\mathrm{TiO} 2$ dan $\mathrm{ZnO}$ untuk cat yang sama (Lv et al., 2019). Pembuatan lapisan cat berbasis semen (cement-based) untuk pendinginan pasif dikembangkan oleh Fajun Wang dengan cara mencampurkan semen Portland putih (WPC), RTV-silicone rubber, dan $\mathrm{TiO}_{2}$; lapisan yang dihasilkan tidak tembus air dan memiliki reflektansi-IR $=87,6 \%$ dan reflektansi-Solar $(\mathrm{TSR})=67 \%(\mathrm{Lv}$ et al., 2019).

Pengembangan cat pemantul panas dengan penambahan pigmen yang memiliki sifat memantulkan cahaya pada Panjang gelombang infra-merah dekat (NIR, Near Infra-Red) yang dilakukan oleh Carlos-Wilbert P. Puessan. Penambahan pigmen NIR dikombinasikan dengan $30 \%$ butiran kaca, dan bahan lain menghasilkan cat akrilik berwarna putih yang mampu menurunkan suhu sebesar $4,79^{\circ} \mathrm{C}$ ke arah timur, dan penurunan suhu sebesar $4,64^{\circ} \mathrm{C}$ ke arah barat. Faktor biaya, durabilitas, efisiensi, dan lingkungan; menjadi perhatian utama dalam mengembangkan pigmen baru yang mampu menyamai kemampuan pigmen berwarna putih mengkilap yang memiliki reflektivitas yang tinggi(Puesan and Mestre, 2017).

Peningkatan kemampuan memantulkan radiasi sinar matahari dapat dilakukan dengan menggunakan cat pemantul panas komersial. Beberapa alternatif lain yang lebih hemat biaya antara lain: untuk penggunaan yang tidak krusial, dapat menggunakan dua lapisan: lapisan cat akrilik putih biasa yang dilapisi dengan pigmen NIR; atau menggunakan cat putih mengkilap. Pada area krusial seperti pipa pendingin ruangan, dapat digunakan insulasi yang menyelubungi sebelum dilakukan pengecatan (Pockett, 2016). Cat akrilik warna putih memiliki kemampuan memantulkan panas yang cukup baik, tetapi cenderung 20\%-25\% lebih mudah memudar dibandingkan warna lain (De Masi, Ruggiero and Vanoli, 2018). Pemilihan jenis atau teknik pendinginan pasif dilakukan dengan memperhitungkan faktor biaya, efisiensi, lingkungan, dan faktor keindahan yang menjadi fungsi penting dari cat itu sendiri.

Penggunaan produk cat pemantul saat ini belum dilengkapi dengan standar mutu produk yang diakui secara nasional. Keberadaan standar nasional diharapkan dapat semakin mendorong upaya pengembangan produk oleh produsen dan melindungi kepentingan konsumen.

\section{METODE}

Metode analisis data pada penelitian ini dilakukan dengan metode studi literatur dan diskusi. Data hasil studi literatur yang digunakan pada penelitian ini bersumber dari dokumen elektronik berupa publikasi jurnal nasional dan internasional; dokumen standar seperti SNI Standar Nasional Indonesia), JIS (Japan 
Industrial Standard), ISO (International Organization for Standardization), dan ASTM (American Society for Testing and Material); regulasi teknis; dokumen spesifikasi teknis (TDS) yang terpublikasi dari pabrik, website, dan sumber lain. Diskusi terkait perkembangan objek penelitian ini antara lain dilakukan dengan pihakpihak seperti BSN (Badan Standarisasi Nasional), Direktorat Industri Kimia Hilir (IKH), APCI (Asosiasi Produsen Cat Indonesia), Pabrik cat di Indonesia, Komite teknis 87-01 Industri cat dan warna, dan laboratorium uji Balai Besar Bahan dan Barang Teknik (B4T). Pengolahan data dilakukan dengan menggunakan pendekatan kualitatif (Semiawan, no date).

\section{HASIL DAN PEMBAHASAN}

Cat pemantul panas merupakan salah satu upaya yang dikembangkan oleh industri cat untuk mendukung program green building secara global dan upaya untuk meningkatkan efisiensi penggunaan energi pada bangunan khususnya di wilayah perkotaan. Pengecatan pada bagian atap atau dak bangunan merupakan alternatif yang relatif murah, sederhana, dan tidak memerlukan perawatan khusus. Penggunaan cat pemantul panas di kota-kota besar di Indonesia (Jakarta, Surabaya, Medan, Palembang, dII) berpotensi untuk dapat menghemat konsumsi energi dan menurunkan emisi gas buang akibat tingginya penggunaan pendingin ruangan.

Standar luar negeri (internasional) terkait spesifikai produk cat pemantul panas yang sudah tersedia diantaranya adalah JIS K5675:2011, "High Solar Reflectance Paint for Roof". Standar JIS ini mencakup jenis produk cat pemantul panas yang membentuk lapisan melalui mekanisme pengeringan udara (air drying) dan digunakan pada bagian atap atau atas bangunan. Spesifikasi mutu cat pemantul panas menurut JIS K5675:2011, terdiri dari 13 parameter uji, yang uraiannya dapat dilihat pada Tabel 1 (JIS K5675-2011, 2011). Klasifikasi dan persyaratan mutu produk menurut JIS disesuaikan dengan iklim dan kondisi di Jepang. Perbedaan iklim di Indonesia dengan Jepang perlu menjadi bahan pertimbangan dalam menentukan parameter uji yang tepat untuk diterapkan di Indonesia.

Persyaratan cat untuk penggunaan pada bangunan atau gedung termasuk bagian atap bangunan yang lebih umum dijelaskan dalam standar ASTM D5324 untuk jenis cat berbasis air dan ASTM D5146 untuk cat berbasis pelarut organik. Menurut ASTM D5324 dan ASTM D5146, parameter uji yang perlu dilakukan terhadap cat untuk bangunan diantaranya pengujian terhadap: 1) cat basah, seperti: kondisi fisik contoh, densitas, kehalusan, derajat keasaman, dan kestabilan penyimpanan; 2) aplikasi, seperti: sifat aplikasi, kekentalan, kerataan, dan waktu pengeringan; 3) sifat lapisan cat, seperti: warna, kilap, reflektansi, dan daya tutup; 4) ketahanan lapisan cat, seperti: kelenturan, ketahanan abrasi, ketahanan terhadap kelembanan, ketahanan terhadap bahan kimia, dan ketahanan terhadap cuaca; 5) komposisi cat, seperti: kandungan bahan organik mudah menguap, kandungan pigmen, pelarut, dan kandungan logam berbahaya (ASTM D532416, 2016) (ASTM D5146-10(2019), 2019).

Spesifikasi produk cat pemantul panas yang dikeluarkan oleh produsen cat atau TDS (Technical Data Sheet) dikembangkan oleh pihak pabrik untuk memberikan informasi kepada konsumaen terkait deskripsi dan keunggulan produk yang dijual. Tabel 1 menampilkan parameter pengujian berdasarkan spesifikasi produk cat pemantul panas dari lima pabrik. Parameter uji yang terdapat pada spesifikasi setiap pabrik tidak sama. Pada umumya spesifikasi pabrik mencantumkan pengujian berikut: waktu pengeringan, appearance, cara pengecatan, padatan total, solar refleftive index (SRI), dan ketahanan terhadap cuaca (ultraviolet) (Aquaproof, 2020) (Nippon Paint, 2020) (AvianBrands, 2020) (Rainguard, 2020) (Sika, 2020).

Pada umumnya suatu produk cat kualitasnya ditunjukkan oleh hasil pengujian terhadap tiga jenis karakteristik, yaitu: tampilan, durabilitas, dan proteksi. Pengujian dilakukan terhadap produk cat basah (sebelum diaplikasikan) dan lapisan kering yang dihasilkan (setelah diaplikasikan). Parameter umum yang diuji terhadap cat basah adalah: Kestabilan penyimpanan, densitas, padatan total, kekentalan, dan kandungan bahan organik mudah menguap (VOC). Parameter uji untuk lapisan cat kering, yaitu: ketahanan gores, daya lekat, ketahanan kimia, ketahanan cuaca atau lingkungan. 
Tabel 1 Parameter uji cat pemantul panas

\begin{tabular}{|c|c|c|c|c|c|c|c|}
\hline No & Parameter Uji & JIS K5675 & spec-1 & spec-2 & spec-3 & spec-4 & spec-5 \\
\hline 1 & Condition in Container & 0 & $x$ & $x$ & $X$ & 0 & 0 \\
\hline 2 & Drying time & 0 & $x$ & 0 & $\mathrm{O}$ & 0 & 0 \\
\hline 3 & Low-temperature Stability & 0 & $x$ & $x$ & $\mathrm{X}$ & $x$ & $x$ \\
\hline 4 & Appearance & 0 & $x$ & $x$ & $x$ & 0 & 0 \\
\hline 5 & Solar Reflectance Index (SRI) & $\mathrm{O}$ & 0 & $x$ & $x$ & 0 & 0 \\
\hline 6 & Falling weight test & $\mathrm{O}$ & $x$ & $x$ & $x$ & $x$ & $x$ \\
\hline 7 & Specular gloss & $\mathrm{O}$ & $x$ & $x$ & $x$ & $x$ & $x$ \\
\hline 8 & Acid resistance & $\mathrm{O}$ & 0 & $x$ & $x$ & $x$ & $x$ \\
\hline 9 & Alkaly resistance & $\mathrm{O}$ & 0 & $x$ & O & $x$ & 0 \\
\hline 10 & Humidity and cool-heat cycling & O & $x$ & $x$ & $x$ & $x$ & $x$ \\
\hline 11 & $\begin{array}{c}\text { Accelerated weathering test } \\
\text { (Xenon) }\end{array}$ & $\mathrm{O}$ & $x$ & $x$ & $x$ & $x$ & $x$ \\
\hline 12 & Adhession & $\mathrm{O}$ & 0 & $x$ & $x$ & 0 & 0 \\
\hline 13 & Outdoor exposure resistance & $\mathrm{O}$ & $x$ & $x$ & $\mathrm{O}$ & $x$ & $x$ \\
\hline 14 & Coverage & $x$ & 0 & 0 & O & 0 & $x$ \\
\hline 15 & Solid Content & $x$ & 0 & $x$ & O & 0 & 0 \\
\hline 16 & Density & $x$ & 0 & 0 & $\mathrm{O}$ & $x$ & 0 \\
\hline 17 & Viscosity & $x$ & 0 & $x$ & $\mathrm{O}$ & $x$ & $x$ \\
\hline 18 & Elongation & $x$ & 0 & $x$ & $x$ & 0 & 0 \\
\hline 19 & Tensile Strength & $x$ & 0 & $x$ & $x$ & 0 & 0 \\
\hline 20 & Water Absorption & $x$ & 0 & $x$ & $x$ & $x$ & $x$ \\
\hline 21 & Durability (UV- weathering test) & $x$ & 0 & $x$ & $\mathrm{O}$ & 0 & 0 \\
\hline 22 & Shelf Life & $x$ & 0 & $x$ & O & 0 & 0 \\
\hline 23 & $\begin{array}{c}\text { surface temperature } \\
\text { decreasing }\end{array}$ & $x$ & $x$ & 0 & $\mathrm{O}$ & 0 & $x$ \\
\hline 24 & lead-free, mercury-free & $X$ & $x$ & $x$ & $\mathrm{O}$ & $x$ & $x$ \\
\hline 25 & Protection time & $x$ & $x$ & $x$ & $\mathrm{O}$ & $x$ & $x$ \\
\hline 26 & VOC & $x$ & $x$ & $x$ & $x$ & 0 & 0 \\
\hline
\end{tabular}

Kestabilan dalam penyimpanan merupakan parameter pengujian yang bertujuan untuk memperkirakan lama waktu suatu produk cat bisa disimpan dan masih dapat digunakan dengan baik. Pengujian ini dapat dilakukan dengan pendekatan alamiah (normal) atau kondisi dipercepat (accelerated). Pengujian secara alamiah pada prinsipnya membiarkan sejumlah spesimen uji pada kondisi penyimpanan sesuai petunjuk pabrik selama kurun waktu tertentu, sedangkan metode dipercepat menggunakan pengaturan kondisi (seperti: suhu dan kelembapan) yang lebih tinggi dari kondisi penyimpanan normal. Metode dipercepat pada umumnya diperlukan waktu pengujian selama 1-2 bulan, sedangkan untuk metode alamiah diperlukan waktu pengujian selama 12-24 bulan. Waktu pengujian merupakan salah satu faktor yang menjadi pertimbangan dalam memilih metode yang sesuai dengan keperluan. Metode penyimpanan secara alamiah akan memberikan hasil yang lebih mewakili kondisi sebenarnya dan cocok untuk digunakan sebagai acuan untuk keperluan penelitian dan pengembangan (riset and development) produk. Pengaturan kondisi pada metode dipercepat dapat dilakukan dengan mengacu kepada standar yang umum digunakan di negara lain seperti ASTM D1849(ASTM D1849-95 (2003), 2003), sehingga hasil yang diperoleh diharapkan dapat menggambarkan kestabilan penyimpanan produk yang diuji. Pada kegiatan inspeksi dan sertifikasi produk, kecepatan waktu pengujian 
menjadi salah satu pertimbangan dalam memilih metode yang akan digunakan.

Densitas atau massa jenis adalah kerapatan benda yang merupakan perbandingan antara massa dengan volume benda. Densitas cat pada umumnya dinyatakan dalam satuan $\mathrm{kg} / \mathrm{L}$ (kilogram per liter). Nilai densitas suatu produk cat sangat bermanfaat untuk mengetahui konsistensi dan gambaran campuran cat yang digunakan. Produsen cat melakukan pengujian densitas untuk kontrol kualitas (quality control) pada saat produksi, sedangkan konsumen melakukan pengujian densitas pada saat menerima barang. Pengukuran densitas dapat menggunakan piknometer, sesuai dengan metode SNI 3564:2014 butir 6.4(SNI 3564:2014, no date), ASTM D1475(ASTM D1475-13, 2013), dan ISO 2811-1(ISO 2811-1, 2016). Metode pengujian densitas yang sederhana dan cepat, memudahkan pihak terkait (produsen, konsumen, atau regulator) untuk dapat melaksanakan inspeksi di lapangan.

Padatan total merupakan parameter pengujian yang menunjukkan bagian tidak menguap dari suatu produk cat. Nilai padatan total dapat menjadi acuan untuk memperkirakan kuantitas lapisan cat kering yang akan terbentuk apabila cat tersebut diaplikasikan. Pada umumnya satuan yang digunakan adalah $\% \mathrm{v} / \mathrm{v}$ (solid volume) atau \% w/w (solid weight). Metode uji yang dapat dijadikan acuan untuk menentukan kandungan padatan total dari cat diantaranya ASTM D2369 untuk solid weight (ASTM D2369-20, 2020) dan ASTM D2697 untuk solid volume(ASTM D2697-03(2014), 2014). Nilai daya sebar teoritis (theoretical coverage) pada saat cat diaplikasikan dengan target ketebalan lapisan kering (dry film thickness) tertentu dapat dihitung dari nilai padatan total (solid volume) dengan menggunakan persamaan-1.

\begin{tabular}{|c|c|}
\hline $\begin{array}{l}T C=\frac{D}{D F T} \\
\text { Dengan: }\end{array}$ & Persamaan-1 \\
\hline $\begin{array}{c}\text { TC } \\
\text { dalam } m^{2} / L\end{array}$ & Theoritical \\
\hline$v / v \quad S V$ & Solid Volume, dalam \% \\
\hline $\begin{array}{r}\text { DFT } \\
\text { dalam } \mu \mathrm{m}\end{array}$ & Dry Film \\
\hline
\end{tabular}

Waktu pengeringan merupakan informasi yang sangat mempengaruhi pada saat cat diaplikasikan. Aplikasi pengecatan pada umumnya terdiri dari beberapa tahap, seperti persiapan permukaan (surface preparation), pemberian lapisan dasar (priming), dan pengecatan akhir (finishing). Proses pengecatan tidak selalu dilakukan satu kali penyemprotan/pengulasan, tetapi seringkali dilakukan secara bertahap atau beberapa kali tergantung sifat cat dan target ketebalan yang diharapkan. Informasi mengenai waktu kering sentuh (touch dry) diperlukan untuk menentukan waktu yang aman suatu lapisan cat dapat disentuh secara perlahan tanpa meninggalkan bekas sentuhan. Waktu selang pengecatan kembali (interval coating time) menentukan kapan lapisan berikut dapat diaplikasikan di atas lapisan yang telah diaplikasikan. Waktu kering keras ( hard dry) adalah waktu suatu lapisan cat sudah tidak menempel apabila disentuh dengan tekanan normal. Waktu kering sempurna (full cure) menunjukkan lapisan cat sudah bereaksi sempurna dan siap untuk digunakan secara optimal, pada umumnya setelah 14 hari. Metode uji yang dapat digunakan untuk menguji waktu pengeringan diantaranya adalah ASTM D1640(ASTM D1640 / D1640M-14(2018), 2018). Waktu pengeringan sangat dipengaruhi oleh beberapa faktor, seperti; suhu, kelembaban, tebal lapisan, dan jenis permukaan yang dilapisi.

Daya lekat suatu lapisan cat merupakan parameter pengujian yang menunjukkan bahwa suatu cat mampu menempel dengan baik pada permukaan material atau lapisan sebelumnya. Pengujian daya lekat pada umumnya dilakukan terhadap lapisan cat yang sudah kering sempurna (full cure) dengan metode crosscut(ISO 2409:2013, 2013) atau metode pulloff(ISO 4624:2016, 2016). Pemilihan metode uji diantaranya, didasarkan kepada: ketebalan lapisan cat kering $(D F T)$, jenis material dasar, dan syarat mutu.

Ketahanan permukaan lapisan cat terhadap faktor-faktor yang terkait dengan tujuan penggunaan atau lingkungan seperti benturan benda jatuh, tetesan atau genangan air, kontak dengan bahan kimia (oli, asam, basa), dan abrasi; perlu dipertimbangkan untuk memastikan keseuaian cat yang digunakan dengan kebutuhannya. Pengujian ketahanan terhadap benturan dapat menggunakan metode menjatuhkan beban pada ketinggian tertentu secara tegak lurus di atas permukaan cat seperti pada ASTM D2794(ASTM D2794-93(2019), 2019). Pengujian ketahanan terhadap bahan kimia (chemical resistance) dapat dilakukan dengan teknik rendam (immersion) atau tetes (spot test), metode yang dapat diacu antara lain ASTM D1308(ASTM D1308-02(2013), 2013).

Ketahanan terhadap cuaca menunjukkan sejauhmana kemampuan lapisan cat mempertahankan fungsinya dalam lingkungan atmosfer aplikasinya. Semakin kuat daya tahan lapisan cat terhadap cuaca, maka 
akan semakin lama umur perlindungan yang dapat ditawarkan. Pengujian ketahanan cuaca menggunakan dua pendekatan, yaitu pengujian secara alamiah (cuaca luar sebenarnya) dan artifisial (dipercepat). Metode pengujian cuaca luar sangat sederhana, yaitu dengan membiarkan sejumlah specimen uji terekspos di lingkungan luar selama kurun waktu tertentu. Metode dipercepat dapat menggunakan alat Ultraviolet- Weathering Test atau Xenon-arc Weathering Test. Hasil pengujian menggunakan metode dipercepat memberikan hasil yang tidak persis sama dengan metode cuaca luar, sehingga korelasinya dibuat berdasarkan pengalaman masing-masing produsen cat. Mengingat pengujian cuaca luar memerlukan waktu yang sangat lama dan kondisi cuaca yang berbeda untuk setiap lokasi, maka metode dipercepat banyak dipilih untuk keperluan inspeksi.

Kandungan bahan berbahaya dalam produk cat saat ini menjadi perhatian global. Dampak terhadap lingkungan dan kesehatan menjadi pertimbangan dalam regulasi yang diberlakukan di beberapa negara. Kandungan senyawa organik mudah menguap (Volatile Organic Compound, VOC) dan logam berat (Pb, $\mathrm{Cd}, \mathrm{Hg}$, dan $\mathrm{Cr}(\mathrm{VI})$ ); termasuk kategori bahan berbahaya yang dibatasi penggunaannya di dalam produk cat. Pengujian kandungan VOC dalam cat dapat dilakukan dengan menggunakan teknik gravimetri untuk cat berbasis pelarut organik dan gravimetrikromatografi untuk cat berbasis air. Metode pengujian kandungan logam berbahaya dapat menggunakan metode AAS (Atomic Absorption Spectrometry) untuk $\mathrm{Pb}$ dan $\mathrm{Cd}$; CV-AAS (Cold Vapour-Atomic Absorption Spectrometry), ICPOES (Inductively Coupled Plasma - Optical Emission Spectrometry) untuk $\mathrm{Pb}, \mathrm{Cd}$, dan $\mathrm{Hg}$; dan UV-Vis Spectrometry untuk $\mathrm{Cr}(\mathrm{VI})$. Persyaratan kandungan bahan berbahaya dapat ditetapkan secara nasional ataupun diharmonisasikan dengan nilai yang telah ditetapkan di negara lain atau internasional. Batasan kandungan VOC di negara Uni Eropa menurut EU-Dirrective 2004/42/CE nilainya berkisar antara $75 \mathrm{~g} / \mathrm{L}$ s.d. $750 \mathrm{~g} / \mathrm{L}$ tergantung dari jenis cat dan penggunaannya (The European Parliament and the Council of the European Union, 2004). Kandungan logam berbahaya pada cat berbasis air menurut SNI 3564:2014, untuk $\mathrm{Pb}<90$ ppm, $\mathrm{Cd}<75$ ppm, $\mathrm{Hg}<60 \mathrm{ppm}$ dan $\mathrm{Cr}(\mathrm{VI})<60 \mathrm{ppm}(\mathrm{SNI}$ 3564:2014, no date); Menurut SNI 8011:2014 untuk cat berbasis pelarut organik kandungan $\mathrm{Pb}<600$ ppm; dan menurut IPEN (International Pollutants Elimination Networks) batasan yang dianjurkan untuk kandungan $\mathrm{Pb}$ adalah maksimum 90 ppm.

Pengujian Solar Reflectance Index (SRI) menjadi parameter kunci yang membedakan antara cat pemantul panas dengan jenis cat yang lain. SRI menunjukkan kemampuan suatu permukaan untuk memantulkan radiasi sinar matahari yang diterima yang dinyatakan dengan skala 0 s.d. 1 $(100 \%)$. SRI diukur pada rentang panjang gelombang $300 \mathrm{~nm}-2500 \mathrm{~nm}$, dan dihitung berdasarkan perbandingan suhu permukaan ( $\left.T_{\text {permukaan }}\right)$ dengan suhu standar warna hitam ( $\left.T_{\text {hitam }}\right)$ dan putih $\left(T_{\text {putih }}\right)$ sesuai persamaan2(Muscio, 2018). Metode pengujian SRI antara lain dapat mengacu kepada ASTM E198011(2019), ISO22969:2019(ISO 22969:2019, 2019) atau JIS K5675. Semakin tinggi nilai SRI suatu permukaan lapisan cat, maka semakin tinggi juga kemampuan permukaan tersebut dalam memantulkan panas dari sinar matahari yang diterima.

$$
\text { SRI }=\frac{T_{\text {hitam }}-T_{\text {permukaan }}}{T_{\text {hitam }}-T_{\text {putih }}} \quad \text {.... Persamaan-2 }
$$

Metode pengambilan contoh untuk keperluan sertifikasi atau pengujian dapat dilakukan dengan mengacu kepada SNI 0465:2014 tentang Pengambilan contoh cat (Semiawan, no date). Dokumen pengambilan contoh perlu dilengkapi dengan identitas yang jelas, kode produksi, lokas pengambilan contoh, tanggal produksi, tipe/jenis, merek, metode pengambilan contoh, jumlah contoh yang diambil, jumlah contoh yang diwakili, dan kondisi kemasan produk saat dilakukan pengambilan contoh.

\section{KESIMPULAN}

Standardisasi terhadap produk cat pemantul panas sangat diperlukan sebagai salah satu bentuk dari upaya pemerintah untuk mendukung industri dalam mengembangkan produk cat pemantul panas yang berkualitas baik dan memiliki daya saing. Beberapa parameter pengujian yang dapat dijadikan bagian dari persyaratan mutu produk antara lain: kestabilan penyimpanan, kondisi dalam kemasan, densitas, padatan total, waktu pengeringan, daya lekat, ketahanan terhadap bahan kimia, ketahanan terhadap cuaca, kandungan senyawa organik menguap (VOC), kandungan logam berbahaya tertentu, dan Solar Reflectance Index (SRI). 


\section{SARAN}

Penyusunan standar spesifikasi produk perlu disesuaikan dengan iklim dan kondisi di masingmasing negara. Cat pemantul panas merupakan produk yang kualitasnya sangat dipengaruhi oleh ketahanannya terhadap lingkungan aplikasi dan iklim. Perkembangan standar spesifikasi untuk produk cat pemantul panas yang telah dipublikasikan di negara lain yang beriklim subtropis, perlu dikaji, diharmonisasikan, dan dilakukan modifikasi sehingga spesifikasi produk sesuai untuk diterapkan di Indonesia.

\section{UCAPAN TERIMA KASIH}

Penulis mengucapkan terima kasih kepada Kepala Balai Besar Bahan dan Barang Teknik, BSN, Direktorat IKHL - Kemenperin, APCI, dan Komtek 87-01 yang telah membantu penelitian ini.

\section{DAFTAR PUSTAKA}

Akbari, H. and Levinson, R. (2008) 'Evolution of cool-roof standards in the US', Advances in Building Energy Research, 2(1), pp. 132. doi: 10.3763/aber.2008.0201.

Aquaproof (2020) 'Heatgard TDS'. Available at:https://aquaproof.co.id/wpcontent/uplo ads/2018/07/heatgard-2.jpg.

ASTM D1308-02(2013) (2013) 'Standard Test Method for Effect of Household Chemicals on Clear and Pigmented Organic Finishes'. West Conshohocken: ASTM Internasional. Available at: www.astm.org.

ASTM D1475-13 (2013) 'Standard Test Method For Density of Liquid Coatings, Inks, and Related Products'. West Conshohocken: ASTM Internasional.

ASTM D1640 / D1640M-14(2018) (2018) 'Standard Test Methods for Drying, Curing, or Film Formation of Organic Coatings'. West Conshohocken: ASTM Internasional.

ASTM D1849-95 (2003) (2003) 'Standard Test Method for Package Stability of Paint', Current, 95(Reapproved), pp. 1-2. doi: 10.1520/D1849-95R08.

ASTM D2369-20 (2020) 'Standard Test Method for Volatile Content of Coatings'. West Conshohocken: ASTM Internasional.

ASTM D2697-03(2014) (2014) 'Standard Test Method for Volume Nonvolatile Matter in Clear or Pigmented Coatings'. West Conshohocken: ASTM Internasional.

ASTM D2794-93(2019) (2019) 'Standard Test Method for Resistance of Organic Coatings to the Effects of Rapid
Deformation (Impact)'. West Conshohocken: ASTM Internasional. Available at: www.astm.org.

ASTM D5146-10(2019) (2019) 'Standard Guide to Testing Solvent-Borne Architectural Coatings', ASTM International.

ASTM D5324-16 (2016) 'Standard Guide for Testing Water-Borne Architectural Coatings', ASTM International.

AvianBrands (2020) 'Sunguard All-In-One'. Available

at: https://avianbrands.com/products/items/s unguard-all-inone?gclid=CjwKCAjw0_T4BRBIEiwAwoE iATFkejwu3z7FJYsCfgX̄u4eNpSsCY2eE 2aLdxsTCczf7TwundZjAXNRoCK9wQAv D BwE.

BPPT (2019) Outlook Energi Indonesia 2019. Edited by A. Sugiyono. Jakarta: PPIPE. doi: 10.1017/CBO9781107415324.004.

Costanzo, V. et al. (2013) 'Study on the application of cool paintings for the passive cooling of existing buildings in mediterranean climates', Advances in Mechanical Engineering, 2013. doi: $10.1155 / 2013 / 413675$.

Eicker, U. (2009) Low Energy Cooling for Sustainable Buildings. John Wiley \& Sons, Ltd. Available at: https://books.google.co.id/books?hl=en\&l $r=$ \&id=whk53fno8CoC\&oi=fnd\&pg=PR5\& ots=MY6 HDDW I\&sig=uOFxboOtxjlAqiSYf79x8zJI4E\&redir_esc $=y \# v$ =onepage \&q\&f=false.

Hutahaean, L. S. (2017) Kebijakan pengembangan industri hijau di indonesia.

ISO 22969:2019 (2019) 'Paints and varnishes Determination of solar reflectance'.

ISO 2409:2013 (2013) 'Paints and varnishes Cross-cut test'. ISO.

ISO 2811-1 (2016) 'Paints and varnishes Determination of density - Part 1: Pycnometer method'. ISO.

ISO 4624:2016 (2016) 'Paints and varnishes Pull-off test for adhesion'. ISO.

JIS K5675-2011 (2011) High Solar Reflectance Paint for Roof.

Kolokotroni, M. et al. (2018) 'Cool roofs: High tech low cost solution for energy efficiency and thermal comfort in low rise low income houses in high solar radiation countries', Energy and Buildings, 176, pp. 58-70. doi: 10.1016/j.enbuild.2018.07.005.

Lubis, I. H. and Koerniawan, M. D. (2018) 'Reducing Heat Gains and Cooling Loads Through Roof Structure Configurations of A House in Medan', IOP Conference Series: Earth and Environmental Science, 
152(1). doi: $\quad 10.1088 / 1755-$ $1315 / 152 / 1 / 012008$.

Lv, J. et al. (2019) 'Synthesis of solar heatreflective $\mathrm{ZnTiO} 3$ pigments with novel roof cooling effect', Ceramics International, 45(12), pp. 15768-15771. doi: 10.1016/j.ceramint.2019.05.081.

Maharjan, S. et al. (2020) 'Highly effective hydrophobic solar reflective coating for building materials: Increasing total solar reflectance via functionalized anatase immobilization in an organosiloxane matrix', Construction and Building Materials, 243, p. 118189 . doi: 10.1016/j.conbuildmat.2020.118189.

De Masi, R. F., Ruggiero, S. and Vanoli, G. P. (2018) 'Acrylic white paint of industrial sector for cool roofing application: Experimental investigation of summer behavior and aging problem under Mediterranean climate', Solar Energy, 169(February), pp. 468-487. doi: 10.1016/j.solener.2018.05.021.

Muscio, A. (2018) 'The solar reflectance index as a tool to forecast the heat released to the urban environment: Potentiality and assessment issues', Climate, 6(1). doi: 10.3390/cli6010012.

Nippon Paint (2020) 'Nippon Weatherbond Solareflect'. Available at: http://www.nipponpaintindonesia.com/products/eksterior-natap/dinding-eksterior\&func=view\&pid $=7$.

Pisello, A. L. (2017) 'State of the art on the development of cool coatings for buildings and cities', Solar Energy, 144, pp. 660680. doi: 10.1016/j.solener.2017.01.068.

Pockett, J. (2016) 'A Review of Heat-reflective Paints', (December 2010).

Puesan, C. W. P. and Mestre, J. L. Z. (2017) 'Technical Evaluation of an Improved Paint Coating with NIR Pigments Designed to Reduce Thermal Discomfort
Caused by Incident Solar Radiation: Application in the Caribbean Area', Energy Procedia, 115, pp. 463-479. doi: 10.1016/j.egypro.2017.05.043.

Rainguard (2020) 'Cool Coat'. Available at: https://rainguardpro.com/product/coolcoat-with-thermdefense/\#techdocs.

Sarazyn, J. (2014) '( 12 ) Patent Application Publication ( 10 ) Pub . No .: US 2014 / 0332121 A1 Eiongation (\%) Patent Application Publication', 1(19), p. 33. Available at: https://patents.google.com/patent/US201 40331942A1/en.

Semiawan, C. R. (no date) 'Metode Penelitian Kualitatif: Jenis, Karakteristik dan Keunggulannya'.

Sika (2020) 'Sika CoolCoat'. Available at: https://bgd.sika.com/en/construction/roofi ng/liquid-applied-membranes/sikacoolcoat.html.

SNI 3564:2014 (no date) 'Cat tembok emulsi'. BSN.

The European Parliament and the Council of the European Union (2004) 'Directive 2004/42/CE of the European Parliament and of the Council of 21 April 2004 on the limitation of emissions of volatile organic compounds due to the use of organic solvents in certain paints and varnishes and vehicle refinishing products and amendi', Official Journal of the European Unio, pp. 87-96. doi: http://eurlex.europa.eu/LexUriServ/LexUriServ.do ?uri=OJ:L:2004:143:0087:0096:EN:PDF.

WGBC (2018) A guide to healthier homes and a healthier planet. Available at: https://www.worldgbc.org/newsmedia/new-guide-outlines-actions-makehomes-healthier-people-and-planet (Accessed: 6 January 2020). 
